\title{
Adjustments in the tetrazolium test methodology for assessing the physiological quality of chickpea seeds ${ }^{1}$
}

\author{
Humberto Alencar Paraíso ${ }^{2 *}$, Delacyr da Silva Brandão Junior ${ }^{2}$, \\ Ramon Ivo Soares Avelar ${ }^{2}$, Candido Alves da Costa ${ }^{2}$, Luan Souza de Paula Gomes ${ }^{2}$, \\ Warley Marcos Nascimento ${ }^{3}$
}

\begin{abstract}
Quick tests are essential tools to evaluate seed quality. The objective of this study was to adapt the methodology of tetrazolium test, by identifying the most suitable pre-conditioning parameters of imbibition temperature and duration, and tetrazolium solution concentrations, in order to assess the physiological quality of chickpea seeds. Also, this work proposed the separation of lots in classes, according to the viability and vigor of the seeds. Three lots of chickpeas (lot 1 - BRS Aleppo C1, lot 2 - BRS Aleppo basic, and lot 3 - Cicero) were evaluated. They were analyzed according to three combinations of imbibition temperature and duration $\left(41^{\circ} \mathrm{C}\right.$ for 4 hours, $41{ }^{\circ} \mathrm{C}$ for 6 hours, and $30^{\circ} \mathrm{C}$ for 18 hours) and two tetrazolium concentrations $(0.1 \%$ and $0.5 \%)$. The imbibition at $41^{\circ} \mathrm{C}$ for 4 or 6 hours, and at $30^{\circ} \mathrm{C}$ for 18 hours allowed clear visualization of injuries in the seeds after immersion in $0.1 \%$ tetrazolium solution. The intense coloration formed by the $0.5 \%$ solution of this salt prevented the differentiation of the types of damage. In addition, it was possible to separate the seeds into four classes: class I (viable and vigorous, without damages), class II (viable and vigorous, with superficial injuries), class III (viable and nonvigorous), and class IV (non-viable).
\end{abstract}

Index terms: Cicer arietinum, seed analysis, viability, vigor.

\section{Adequação do teste de tetrazólio para avaliação da qualidade fisiológica de sementes de grão-de-bico}

\begin{abstract}
RESUMO - Testes rápidos são ferramentas imprescindíveis na avaliação da qualidade de sementes. O objetivo deste estudo foi adequar a metodologia do teste de tetrazólio para avaliar a qualidade fisiológica de sementes de grão-de-bico, visando a identificação dos melhores tempos e temperaturas de pré-condicionamento, e concentrações das soluções de tetrazólio. Além disso, foi proposta uma separação em classes quanto à viabilidade e vigor das sementes. Foram avaliados três lotes de sementes de grão-de-bico (lote 1 - 'BRS Aleppo' C1, lote 2 - 'BRS Aleppo' básico e lote 3 - 'Cícero' básico), três binômios tempo-temperatura de embebição $\left(41^{\circ} \mathrm{C}\right.$ por 4 horas, $41^{\circ} \mathrm{C}$ por 6 horas e $30^{\circ} \mathrm{C}$ por 18 horas) e duas concentrações de tetrazólio $(0,1 \%$ e $0,5 \%)$. As condições de embebição de $41{ }^{\circ} \mathrm{C}$ por 4 ou 6 horas e de $30{ }^{\circ} \mathrm{C}$ por 18 horas permitiram visualizar de forma clara os danos ocorridos nas sementes quando imersas em solução $0,1 \%$ de tetrazólio. A coloração intensa formada nas sementes submetidas à concentração de $0,5 \%$ do sal impediu a diferenciação dos tipos de danos. Além disso, foi possível realizar a separação em quatro classes, sendo viáveis as sementes das classes I, II e III, vigorosas as das classes I e II e não viáveis as da classe IV.
\end{abstract}

Termos para indexação: Cicer arietinum, análise de sementes, viabilidade, vigor.

\section{Introduction}

Chickpeas (Cicer arietinum L.) is remarked as one of the primary legumes among food grains (Artiaga et al., 2015).
Its cultivation takes place in several places worldwide and, in some regions, it has acquired an essential socioeconomic role. These grains have good nutritional value and can be used in both human and animal feed, as well as in medicine and the

\footnotetext{
${ }^{1}$ Submitted on 11/13/2017. Accepted for publication 10/22/2018. ${ }^{2}$ Instituto de Ciências Agrárias (ICA) - UFMG - Campus Regional de Montes Claros, 39404-547 - Montes Claros, MG, Brasil.
}

${ }^{3}$ EMBRAPA Hortaliças, Caixa Postal: 218, 70275-970 - Brasília, DF, Brasil. *Corresponding author <humbertoagrocivil@yahoo.com.br> 
industry (Al-Snafi, 2016; Nascimento et al., 2016).

Brazil does not have a tradition of producing chickpeas for commercial purposes. However, this culture has been adapting very well to the edaphoclimatic conditions of the Brazilian Cerrado, thus creating a good perspective as for its cultivation in the country (Artiaga et al., 2015). The expansion of the species depends on a series of factors, including the need for improving the seed production system. In the process of establishment of crops, for instance, it is essential that seeds have high physic, physiological, genetical, and sanitary quality (Talamini et al., 2011; Resende et al., 2015).

Many methods are used to assess the physiological quality of seeds. The germination test is universally used in quality control programs, even though, in its usual form, it does not provide information regarding seed vigor. Also, depending on the plant analyzed, obtaining the results might consume a considerable amount of time - in several cultivated species, including chickpea, this test takes longer than 7 days (Brasil, 2009).

On account of that, the tetrazolium test is an interesting alternative to assess the physiological potential of seeds, with the advantages of being fast and providing a detailed analysis of both viability and vigor. In general, it can be concluded within less than 24 hours (Silva et al., 2013; Carvalho et al., 2014; Oliveira et al., 2014; Rodrigues et al., 2015), and it makes possible to identify the presence, location, and nature of eventual damages in the seeds. Such a more complete analysis is not provided by the standard germination test (França-Neto et al., 1998; Marcos-Filho, 2005).

In the tetrazolium test, dehydrogenase enzymes act in cell respiration, producing a red, stable, non-diffusive substance. This compound, called triphenyl formazan, is formed from the hydrogenation of 2,3,5-triphenyl tetrazolium chloride. As a result of this reaction, the living parts of the seed are tinted red, while the dead ones keep the original color, thus allowing to distinguish the tissues by their condition (Abbade and Takaki, 2014).

To perform the tetrazolium test, it is necessary to define pre-conditioning settings, such as temperature and duration of imbibition, 2,3,5-triphenyl tetrazolium chloride solution concentration, and the exposure method of the seeds to coloration. There is no specific methodology in Rules for Seed Testing (RAS) recommending the tetrazolium test for chickpeas. Nonetheless, Rao et al. (2006) suggest conducting the imbibition of chickpea seeds at $30{ }^{\circ} \mathrm{C}$ for 18 hours. After that, they should be exposed to a $1 \%$ tetrazolium solution at $30{ }^{\circ} \mathrm{C}$ for 6 to 24 hours.

The present work was developed aiming at adjusting the tetrazolium test methodology to evaluate the physiological quality of chickpea seeds, so that better pre-conditioning settings of time, temperature, and reagent concentration can be identified. Another objective was to sort the seeds according to their viability and vigor.

\section{Material and Methods}

The experiment was carried out in the Laboratory of Seed Analysis at the Instituto de Ciências Agrárias, belonging to Universidade Federal de Minas Gerais (LAS-ICA/UFMG). Physiological parameters of chickpea seeds were appraised by the tetrazolium and germination tests.

For the tetrazolium test, a completely randomized design was applied, in a $3 \times 3 \times 2$ factorial scheme: lots, seed preconditioning settings, and tetrazolium solution concentration, respectively. In this case, four replications of 25 seeds per treatment were used.

The first lot was composed by seeds of the cultivar $B R S$ Aleppo C1 (2015 harvest); the second by the cultivar BRS Aleppo basic (2014/2015 harvest); and the third lot by the cultivar Cícero (2014 harvest). The seeds of each lot were subjected to three pre-conditioning settings, as follows: 1) imbibition at $41{ }^{\circ} \mathrm{C}$ for 4 hours; 2) imbibition at $41{ }^{\circ} \mathrm{C}$ for 6 hours; and 3) imbibition at $30^{\circ} \mathrm{C}$ for 18 hours. After that, the seeds had their tegument removed, and they were exposed to $0.1 \%$ or $0.5 \% 2,3,5$-triphenyl tetrazolium chloride solutions, at $30{ }^{\circ} \mathrm{C}$ for 6 hours.

The settings of tetrazolium concentration and imbibition duration and temperature were determined based on recommendations made for soybean and chickpea seeds, by Rules for Seed Testing and by the Manual of Seed Handling in Genebanks, respectively (Brasil, 2009; Rao et al., 2006).

The seeds were pre-conditioned on Germitest ${ }^{\circledR}$ paper moistened 2.5 times its weight with distilled water. The evaluations were performed individually, first by longitudinally cutting open the seeds and separating the cotyledons. Then, the outside and inside parts were checked for damages with the aid of a stereoscopic microscope. The location, depth, and extension of each injury were decisive to read the results.

The information gathered from each seed allowed to sort them into classes according to viability and vigor. The classification proceeded as follows: Class I) viable and vigorous seeds (without injuries); Class II) viable and vigorous seeds (with superficial injuries); Class III) viable and non-vigorous seeds; and Class IV) non-viable seeds.

The germination test was conducted inside a BOD chamber at a constant temperature of $20^{\circ} \mathrm{C}$. Germitest ${ }^{\circledR}$ paper rolls were used as the substrate. The assessments were carried out on the fifth and eighth days after the test setup, when the 
percentage of normal seedlings was accounted (Brasil, 2009). Also, daily readings of the radicle protrusion were done, and the germination speed index (GSI) was calculated through the equation proposed by Maguire (1962). Four replications of 25 seeds per lot were performed.

The data were submitted to analysis of variance, and the means were compared by the Tukey's test at a 5\% probability level, with the statistic software R (The R Foundation, 2013).

\section{Results and Discussion}

The analysis of the physiological potential of chickpea seeds showed difference among the lots regarding the germination percentage (Table 1). Lot 1 exhibited the highest rate of emerged seeds (92\%), whereas lot 3 showed an intermediate value $(50 \%)$, and lot 2 the lowest one $(16 \%)$. Therefore, according to the germination test, seeds from lot 1 were the most viable ones.

Such a difference was attributed to seed storage duration: the longer it took, the lower was the germination percentage of the corresponding lot. In this sense, since the seed lots had come from distinct harvest moments, their storage time varied. So, lot 1 was the youngest, followed by lots 3 and 2, in that order. As stated by Almeida et al. (1997), germination and vigor indices significantly decrease after seed storage.

During the germination test, more intense fungus growth was observed in the two lots with the longest storage duration, which also suffered a more considerable reduction in the germination potential (especially lot 2). This fact validates the affirmation that the storage time was the primary responsible for compromising germination, that is, the older the lot, the lower the viability of the seeds. As a consequence, storage fungi were able to proliferate in non-viable seed tissues.

Regarding the germination speed index (GSI), lot 3 stood out from the others for presenting the highest value for this variable (Table 1).

In the tetrazolium test, the intense color produced by the $0.5 \%$ solution made it difficult to differentiate the types of damages (Figure 1). Thus, the parameters were analyzed only when the $0.1 \%$ solution was used. The efficiency of the staining at the $0.1 \%$ concentration is similar to that used for Glycine max seed tests (França-Neto et al., 1988), which is much lower than that recommended by Rao et al. (2006).

As for moisture content after the imbibition test, specifically in lot 3 , the treatment at $30^{\circ} \mathrm{C}$ for 18 hours differed from that conducted at $41{ }^{\circ} \mathrm{C}$ for 6 hours, but it was not distinct from the one performed at $41^{\circ} \mathrm{C}$ for 4 hours. Also, this was the only treatment that showed a difference between the conditions of $41{ }^{\circ} \mathrm{C}$ for 4 hours and those of $41{ }^{\circ} \mathrm{C}$ for 6 hours. Within each pre-conditioning treatment, seed lots 1 and 2 differed from each other when they were tested at $41{ }^{\circ} \mathrm{C}$ for 4 hours. The highest water absorption rate was observed at $30{ }^{\circ} \mathrm{C}$ for 18 hours $(33 \%)$, and the lowest was at $41{ }^{\circ} \mathrm{C}$ for 4 hours $(23 \%)$ (Table 1$)$.

Table 1. Mean data of the germination percentage (G), germination speed index (GSI), and moisture content (after imbibition) of chickpea seeds.

\begin{tabular}{cccccc}
\hline \multirow{2}{*}{ Seed lots } & G (\%) & GSI & \multicolumn{3}{c}{ Moisture content (\%) } \\
\cline { 4 - 5 } & & $12.5 \mathrm{~b}$ & $32.87 \mathrm{Aa}$ & $22.97 \mathrm{Bb}$ & $6 \mathrm{~h} / 41^{\circ} \mathrm{C}$ \\
\hline Lot 1 & $92.0 \mathrm{a}$ & $10.9 \mathrm{~b}$ & $32.72 \mathrm{Aa}$ & $26.82 \mathrm{Ba}$ & $24.19 \mathrm{Ba}$ \\
Lot 2 & $16.0 \mathrm{c}$ & $15.9 \mathrm{a}$ & $30.38 \mathrm{Aa}$ & $27.30 \mathrm{Aab}$ & $24.16 \mathrm{Ba}$ \\
Lot 3 & $50.0 \mathrm{~b}$ & 9.12 & & 9.66 \\
\hline CV $(\%)$ & 18.8 & & \\
\hline
\end{tabular}

Means followed by the same lowercase letter do not statistically differ among themselves, according to the Tukey's test at a 5\% probability level. Data were transformed by the function.

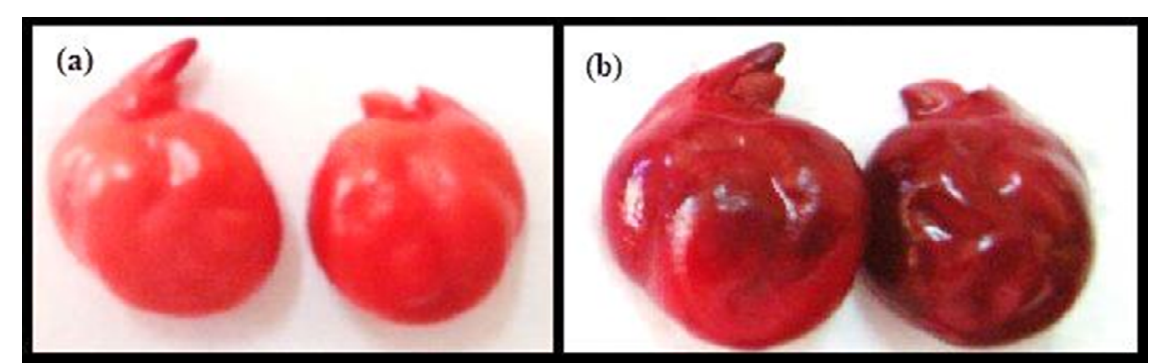

Figure 1. Difference of coloration in chickpea seeds exposed to $0.1 \%$ (a) and $0.5 \%$ (b) tetrazolium solutions. 
According to Costa et al. (2008), above 25\% is the ideal moisture content range for performing the tetrazolium test; whereas, below $24 \%$, the formation of color is compromised. Despite those author's remarks, in this study, moisture contents below $27 \%$ did not interfere in the coloration of chickpea seeds.

The analyses of viability and vigor proposed sorting seeds by classes. Class I included seeds with firm tissues, even coloration along the whole extension of the embryo, and absence of injuries. The seeds from this class were considered viable and vigorous (Figure 2).

Class II was composed of seeds with generally firm tissues, almost entirely uniform coloration, and some superficial injuries. In this case, the damages were located far from the embryonic axis and other vital parts, and the seeds were classified as viable and vigorous. (Figure 2).

Class III grouped seeds with injuries in the embryonic axis and other vital parts, but which did not affect the cylindrical-central region. Some of them had significant extensions of dead tissues and several types of damages acting simultaneously. Seeds from this class were considered viable and non-vigorous (Figure 2).
Class IV contained seeds with damages that compromised the normal seedling development, so that they were considered not viable. This class comprised dead seeds, and also those with embryonic tissues without respiration, living embryonic axis with dead cotyledons, and necrotized or absent embryos.

The evaluation of chickpeas according to the aforementioned classification showed no interaction between the lots and the conditions of temperature and duration of imbibition. The lots differed from each other as for seed viability, with lot 1 presenting $94.7 \%$ of viable seeds, whereas lots 2 and 3 showed $64.5 \%$ and $86.5 \%$, respectively. Regarding the vigor analysis, lot 1 behaved differently from the rest, thus being considered the one with the highest viability and vigor. On the other hand, lot 2 was the least viable of them (Table 2).

As for the duration and temperature of imbibition, there was no difference in the viability of the lots. Nevertheless, when it came to seed vigor, the treatment conducted at $30^{\circ} \mathrm{C}$ for 18 hours differed from the others. It presented the highest percentage of vigorous seeds $(44.8 \%)$, while the lowest value for this parameter was observed at $41^{\circ} \mathrm{C}$ for 4 hours (Table 2).

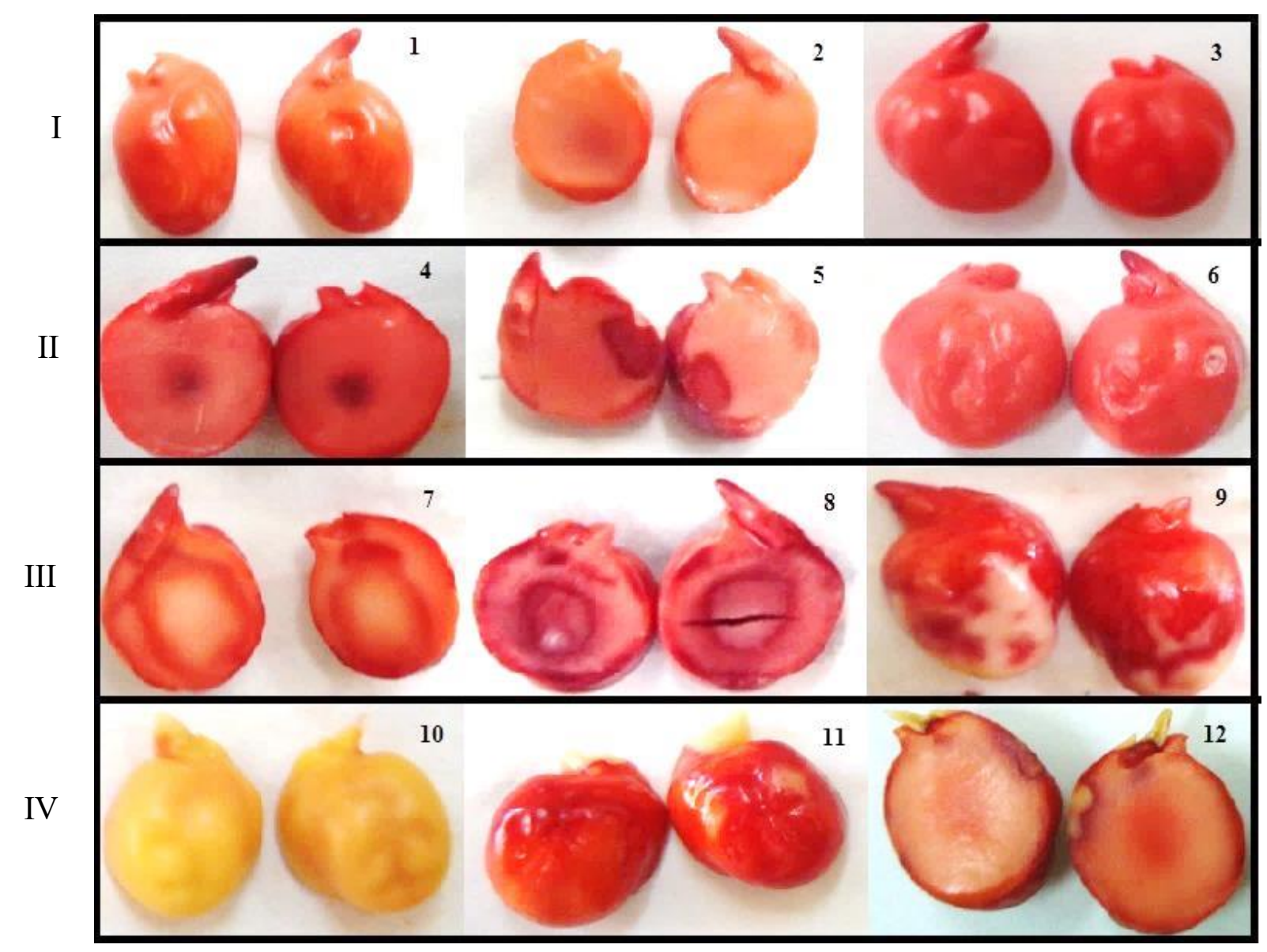

Figure 2. Chickpea seeds separated into classes for evaluation of viability and vigor by the tetrazolium test. Class I (1-3), class II (4-6), class III (7-9), and class IV (10-12). 
Table 2. Mean percentage values of viability and vigor of chickpea seeds assessed by the tetrazolium test, as a function of the different cultivars/ classes and the imbibition conditions of temperature and duration.

\begin{tabular}{lcc}
\hline \multicolumn{1}{c}{ Cultivar/ Class } & TZ Viability $(\%)$ & TZ Vigor $(\%)$ \\
\hline Lot 1 & $94.67(1.36) \mathrm{a}$ & $83.67(1.18) \mathrm{a}$ \\
Lot 2 & $64.50(0.94) \mathrm{c}$ & $11.00(0.30) \mathrm{b}$ \\
Lot 3 & $86.50(1.21) \mathrm{b}$ & $15.50(0.39) \mathrm{b}$ \\
\hline Temperature/ & TZ Viability $(\%)$ & TZ Vigor $(\%)$ \\
Imbibition duration & & \\
\hline $41{ }^{\circ} \mathrm{C}-4$ hours & $79.33(1.13) \mathrm{a}$ & $30.67(0.51) \mathrm{b}$ \\
$41{ }^{\circ} \mathrm{C}-6$ hours & $80.75(1.16) \mathrm{a}$ & $34.75(0.60) \mathrm{b}$ \\
$30{ }^{\circ} \mathrm{C}-18$ hours & $85.58(1.22) \mathrm{a}$ & $44.75(0.75) \mathrm{a}$ \\
\hline $\mathrm{CV}(\%)$ & 9.16 & 19.93 \\
\hline
\end{tabular}

Means followed by the same lowercase letter do not statistically differ among themselves, according to the Tukey's test at a 5\% probability level. Data were transformed by the function.

A comparison between the results of the tetrazolium and germination tests showed the same sequence of viability, that is, in both analyses, lot 1 presented the highest amount of viable seeds, followed by lots 2 and 3, in that order. On the other hand, the outcome of these tests differed significantly from one another. Regarding seed vigor, the tetrazolium experiment and the germination speed index (GSI) also exhibited diverging results.

In summary, the imbibition at $41{ }^{\circ} \mathrm{C}$ for 4 or 6 hours and at $30^{\circ} \mathrm{C}$ for 18 hours allowed the visualization of damages in the seeds when they were submerged in a $0.1 \%$ tetrazolium solution. On the other hand, using a $0.5 \%$ solution of this salt produced a color too intense, which impaired the differentiation of the injury types. Also, pre-conditioning seeds in Germitest ${ }^{\circledR}$ paper made it hard to remove the tegument for the following coloration process. In this case, submerging seeds in water inside plastic boxes (gerboxes) might be a solution.

As a final remark, additional studies are still required to perfect the methodology for determination of viability and vigor of chickpea seeds by the tetrazolium test.

\section{Conclusions}

The intense color produced in chickpea seeds by the $0.5 \%$ tetrazolium solution hinders the differentiation of injury types.

The imbibition conditions of $41^{\circ} \mathrm{C}$ for 4 or 6 hours and $30^{\circ} \mathrm{C}$ for 18 hours allow visualizing damages in chickpea seeds when they are submerged in a $0.1 \%$ tetrazolium solution.

Pre-conditioning chickpea seeds on Germitest ${ }^{\mathbb{R}}$ paper makes it hard to remove the tegument for the following coloration process. Submerging them in water inside plastic boxes (gerboxes) might be a solution.

\section{References}

ABBADE, L.C.; TAKAKI, M. Teste de tetrazólio para avaliação da qualidade de sementes de Tabebuia roseoalba (Ridl.) Sandwith Bignoniaceae, submetidas ao armazenamento. Revista Árvore, v.38, n.2, p.233-240, 2014. http://www.scielo.br/scielo.php?pid=S0100$67622014000200003 \&$ script $=$ sci_abstract\&tlng=pt

ALMEIDA, L.D.; BRAGA, N.R.; SANTOS, R.R.; GALLO, P.B.; PEREIRA, J.C.V.N.A. Comportamento de sementes de grão-de-bico na armazenagem. Bragantia, v.56, n.1, p.97-102, 1997. http://www.scielo. br/scielo.php?script=sci_arttext\&pid=S0006-87051997000100011

AL-SNAFI, A.E. The medical importance of Cicer arietinum-A review. IOSR Journal of Pharmacy, v.6, n.3, p.29-40, 2016. https://pdfs. semanticscholar.org/6f12/78005ad5ff62d6e3ac7bfaf36becce7ce51f.pdf

ARTIAGA, O.P.; SPEHAR, C.R.; BOITEUX, L.S.; NASCIMENTO, W.M. Avaliação de genótipos de grão de bico em cultivo de sequeiro nas condições de cerrado. Revista Brasileira de Ciências Agrárias, v.10, n.1, p.102-109, 2015. http://www.agraria.pro.br/sistema/index.php?journal $=$ agraria\&page $=$ article $\&$ op $=$ view $\&$ path $\% 5 \mathrm{~B} \% 5 \mathrm{D}=$ agraria v10i1a5129\&path $\% 5 B \% 5 \mathrm{D}=1758$

BRASIL. Ministério da Agricultura, Pecuária e Abastecimento. Regras para análise de sementes. Ministério da Agricultura, Pecuária e Abastecimento. Secretaria de Defesa Agropecuária. Brasília: MAPA/ACS, 2009. 395p. http://www.agricultura.gov.br/arq_editor/ file/2946_regras_analise_sementes.pdf

CARVALHO, T.C.; GRZYBOWSKI, C.R.S.; OHLSON, O.C.; PANOBIANCO, M. Adequação da metodologia do teste de tetrazólio para estimar a viabilidade de sementes de sorgo. Journal of Seed Science, v.36, n.2, 2014. http://submission.scielo.br/index.php/jss/ article/view/101959/8781

COSTA, N.P.; MARCOS-FILHO, J.; FRANÇA-NETO, J.B.; KRZYZANOWSKI, F.C.; HENNING, A.A. Teste de tetrazólio em sementes de soja com pré condicionamento abreviado - Série Sementes. Londrina: Embrapa-CNPSo, 2008. https://www. embrapa.br/soja/busca-de-publicacoes/-/publicacao/471078/ teste-de-tetrazolio-em-semente-de-soja-com-precondicionamentoabreviado-serie-sementes

FRANÇA-NETO, J.B.; KRZYZANOWSKI, F.C.; COSTA, N.P. $\mathrm{O}$ teste de tetrazólio em sementes de soja. (EMBRAPA-CNPSo. Documentos, 116). Londrina: EMBRAPA-CNPSo, 1998. 72p. https:// www.agrolink.com.br/downloads/TRETRAZ\%C3\%93LIO.pdf

MAGUIRE, J.D. Speed of germination aid seedling emergence and vigor. Crop Science, v.2, n.2, p.176-177, 1962. https:// dl.sciencesocieties.org/publications/cs/abstracts/2/2/CS0020020176

MARCOS-FILHO, J. Fisiologia de sementes de plantas cultivadas. Piracicaba: FEALQ, 2005. 495p.

NASCIMENTO, W.M.; SILVA, P.P.; ARTIAGA, O.P.; SUINAGA, F.A. Grão-de-bico. Hortaliças Leguminosas. Brasília, DF: Empresa Brasileira de Pesquisa Agropecuária, 2016. p.89-118. 
OLIVEIRA, L.M.; GOMES, J.P.; SOUZA, G.K.; NICOLETTI, M.F.; LIZ, T.O.; PIKART, T.G. Metodologia alternativa para o teste de tetrazólio em sementes de Araucaria angustifolia (Bertol.) Kuntze. Floresta e Ambiente, v.21, n.4, 2014. http://www.scielo.br/scielo.php?script=sci_ arttext\&pid=S2179-80872014000400006

R FOUNDATION. $R$ : the R project for statistical computing. R Vienna: The R Foundation, 2013. https://www.r-project.org/.

RAO, N.K.; HANSON, J.; DULLOO, M.E.; GHOSH, K.; NOWELL, A.; LARINDE, M. Manual of seed handling in genebanks. Handbooks for Genebanks No. 8, Bioversity International: Rome, Italy, 2006. 163p.

RESENDE, R.G.; JESUS, L.L.; NERY, M.C.; ROCHA, A.S.; CRUZ, S.M.; ANDRADE, P.C.R. Teste de tetrazólio em sementes de crambe. Semina: Ciências Agrárias, v.36, n.4, 2015. http://www.uel. br/revistas/uel/index.php/semagrarias/article/viewFile/13453/16781

RODRIGUES, A.P.M.S.; MENDONÇA JÚNIOR, A.F.; TORRES, S.B.; NOGUEIRA, N.W.; FREITAS, R.M.O. Teste de tetrazólio para avaliação da qualidade fisiológica de sementes de Vigna unguiculata (L.) Walp. Revista Ciência Agronômica, v.46, n.3, 2015. http://www. ccarevista.ufc.br/seer/index.php/ccarevista/article/view/3658/1165
SILVA, R.C.; GRZYBOWSKI, C.R.S.; FRANÇA-NETO, J.B.; PANOBIANCO, M. Adaptação do teste de tetrazólio para avaliação da viabilidade e do vigor de sementes de girassol. Pesquisa Agropecuária Brasileira, v.48, n.1, p.105-113, 2013. http://www. scielo.br/pdf/pab/v48n1/14.pdf

TALAMINI, V.; ALMEIDA, N.A.; LIMA, N.R.S.; SILVA, A.M.F.; CARVALHO, H.W.L.; SOUSA, R.C. Avaliação da qualidade física, fisiológica e sanitária de sementes de girassol introduzidas para o cultivo em Sergipe. Embrapa Tabuleiros Costeiros-Boletim de Pesquisa e Desenvolvimento (INFOTECA-E), 2011. http://www. cpatc.embrapa.br/publicacoes_2011/bp_67.pdf 